\title{
PENGARUH CAPITAL ADEQUACY RATIO, NON PERFORMING LOAN, BIAYA OPERASIONAL PENDAPATAN OPERASIONAL, DAN LOAN TO DEPOISIT RATIO TERHADAP PERUBAHAN LABA ( Studi Kasus Bank Konvensional Yang Terdaftar di BEI Periode 2009-2012)
}

\author{
Dita Nur Raifah ${ }^{1} *$ Teguh Erawati $^{2}$
}

\begin{abstract}
This study discusses the changes in earnings and financial ratios based on financial statements of listed companies in Indonesia Stock Exchange during the period 2009-2012. The purpose of this study was to determine whether the Capital Adequacy Ratio (CAR), NonPerforming Loans (NPL), Operating Expenses Operating Income (BOPO), and the Loan to Deposit Ratio $(L D R)$ has an influence on incomen changes.

The type of data in this study is secondary. Sampling in this study using purposive sampling method. Companies that used a sample of 24 banking companies listed in Indonesia Stock Exchange during 2009-2012. This research is quantitative, and statistical tests use the test multiple linear regression

By using regression analysis, it can be seen that the Capital Adequacy Ratio (CA ), Non Performing Loans (NPL), Operating Expenses Operating Income (BOPO), and the Loan to Deposit Ratio (LDR) has a significant effect on earnings changes. Partial test results, the Capital Adequacy Ratio (CAR) has a positive and significant effect on earnings changes . Non Performing Loan (NPL) had no effect on earnings changes . Operating Expenses Operating Income does not affect the income changes. Loan to Deposit Ratio (LDR) has a positive and significant effect on earnings changes .
\end{abstract}

Keywords : Capital Adequacy Ratio (CAR), Non-Performing Loans (NPL), Operating Expenses Operating Income (BOPO), and the loan to deposit ratio (LDR), and Income Changes .

\footnotetext{
${ }^{1}$ Alumni Program Studi Akuntansi Fakultas Ekonomi Universitas Sarjanawiyata Tamansiswa *Ditha_dody@yahoo.com
} 


\section{A. PENDAHULUAN \\ 1. Latar Belakang}

Intitusi perbankan merupakan tempat untuk menghimpun dana dan mengalokasikan dana, intitusi perbankan menjadi daya tarik tertentu karena hanya perbankan yang memiliki fungsi tersebut. Kinerja institusi perbankan dapat dipersandingkan dengan kinerja suatu pemerintahan karena institusi ini melaksanakan fungsi sebagai fasilitator keuangan. Pada krisis melanda Negara institusi perbankan turut serta dan bertanggung jawab dalam keterpurukan perekonomian Negara. Perbankanlah yang dapat meningkatkan aktivitas pembangunan nasional dan perbankan dapat menghambat roda perekonomian (Aviliani,2007).

Kinerja perusahaan dari sisi manajemen dapat dilihat dari laba yang tinggi karena semakin tinggi laba perbankan semakin flexible perusahaan dalam menjalankan aktivitas operasional perusahaan. Pada posisi Desember 2004 DPK mengalami kenaikan 4,99 \% pada posisi Juni 2005 naik menjadi 10,73\% dibanding posisi yang sama pada Juni 2004. Penyaluran kredit periode Juni 2004 mengalami kenaikan $12,47 \%$ dibanding dengan posisi Desember 2004 naik menjadi $28,09 \%$ dibandingkan posisi yang sama pada Juni 2004. Dalam indikator ini dapat dikatakan bahwa telah terjadi peningkatan kemampuan operasional perbankan, namun demikian tidak diikuti dengan kemampuan bank untuk meraih profitabilitas (Aviliani,2007).

Selama semester 1 tahun 2005, hampir seluruh bank menunjukan penurunan ROA dan ROE, sementara terjadi peningkatan biaya operasional. ROA menunjukkan penurunan dilihat dengn menggunakan nilai rata-rata pada posisi Juni 2004 sebesar 3,05 \%, pada posisi Desember 2005 mengalami kenaikan sebesar 3.33 dan posisi Juni 2005 mengalami penurunan sebesar 2.68. ROE pada posisi Juni 2004 sebesar $31.27 \%$, pada posisi Desember 2004
ROE meningkat menjadi $42,94 \%$, sedangkan pada posisi Juni 2005 ROE menurun menjadi $24,20 \%$. Biaya Operasional Pendapatan Operasional (BOPO) pada posisi Juni 2004 sebesar $73,41 \%$, BOPO diposisi Desember 2004 mengalami penurunan menjadi 72.56, dan pada posisi Juni 2005 BOPO terjadi peningkatan sebesar 76.08 Hal yang sama juga terjadi selama periode 1 tahun ( Juni 2004 Juni 2005). Laba hampir diseluruh bank menurun (Aviliani,2007).

Kesehatan bank menurun, dilihat dari fungsi perbankan sebagai intermediator keuangan yang tercerminkan dengan tingkat LDR, pada bulan Juni 2005 LDR perbankan nasional tercatat $61,45 \%$. Terdapat kenaikan yang signifikan pada periode Juni 2005 sebesar 7,13 \% atau ekspansi kredit Rp 69,1 Triliun dibanding dengan periode Desember 2004 mengalami kenaikan $15,68 \%$ atau ekspansi kredit Rp 136,5 Triliun. Kenaikan ini sebenarnya cukup menggembirakan karena perbankan telah berhasil menyalurkan dana rata-rata $\mathrm{Rp}$ 9-10 Triliun perbulan. Namun kredit-kredit yang disalurkan memberikan kontribusi optimal dalam pencapaian laba. Selama semester 2 tahun 2004, hampir seluruh bank papan atas mengalami perbaikan dalam mengelola portofolio kredit. Hal ini terlihat semakin mengecilnya NPL. Secara serentak keadaan itu membaik karena pada semester 1 tahun 2005 kondisi NPL sangat memprihatinkan. NPL dari hampir seluruh bank menurun drastis. Rata-rata terjadi pertumbuhan NPL 84,2\% hanya dalam waktu 6 bulan. Ekspansi kredit yang berlangsung selama semerter 1 tahun 2005 tidak memberikan kontribusi dalam perolehan laba bank. Yang terjadi justru sebaliknya, perbankan harus rela mengurangi laba untuk Penyisihan Penghapusan Aktiva Produktif (Aviliani,2007).

Penulis tertarik untuk melakukan penelitian lebih lanjut terhadap perubahan laba pada bank konvensional di Indonesia melanjutkan penelitian dari Dewanti (2009). Perbedaan penelitian ini dengan penelitian 
sebelumnya terletak di variabel CAR, objeß. METODOLOGI PENELITIAN penelitian dan periode penelitian.

\section{Rumusan Masalah}

Berdasarkan latar belakang yang dipaparkan, maka perumusan masalah pada penelitian ini adalah sebagai berikut:

a. Apakah variabel Capital Adequacy Ratio mempunyai pengaruh terhadap perubahan laba pada bank konvensional yang terdaftar di Bursa Efek Indonesia?

b. Apakah variabel Non Performing Loans mempunyai pengaruh terhadap perubahant. laba pada bank konvensional yang terdaftar di Bursa Efek Indonesia?

c. Apakah variabel Biaya Operasional Pendapatan Operasional mempunyai pengaruh terhadap perubahan laba pada bank konvensional yang terdaftar di Bursa Efek. Indonesia?

d. Apakah variabel Loan to Deposit Ratio mempunyai pengaruh terhadap perubahan laba pada bank konvensional yang terdaftar di Bursa Efek Indonesia ?

e. Apakah variabel Capital Adequacy Ratio, Non Performing Loan, Biaya Operasional Pendapatan Operasional, dan Loan to Deposit Ratio secara simultan mempunyai pengaruh terhadap perubahan laba pada bank konvensional yang terdaftar di Bursa Efek Indonesia?

Dalam penelitian ini digunakan dua variabel, yaitu variabel dependen dan independen. Dalam penelitian ini, variabel dependen adalah Perubahan Laba yang dinyatakan dalam persen dan variabel independen adalah Capital Adequacy Ratio, Non Performing Loan, Biaya Operasional Pendapatan Operasional, dan Loan to Deposit Ratio.

\section{Sifat Penelitian}

Sifat dalam penelitian ini adalah kuantitatif, dengan data sekunder dan dalam pengolahan datanya menggunakan model statistik.

\section{Metode Pengumpulan Data}

Metode pengumpulan data dalam penelitian ini dilakukan dengan Studi pustaka yaitu dengan melakukan telaah pustaka, eksplorasi dan mengkaji berbagai literatur pustaka seperti jurnal, skripsi, tesis dan sumber - sumber lain yang berkaitan dengan penelitian dan dokumentasi yaitu dengan mengumpulkan data dengan cara mencatat dokumen yang berhubungan dengan penelitian.

\section{Definisi Operasional Variabel}

\begin{tabular}{|l|l|l|}
\hline \multicolumn{1}{|c|}{ Indikator } & \multicolumn{1}{|c|}{ Definisi Indikator } & Pengukuran \\
\hline Perubahan & $\begin{array}{l}\text { Laba merupakan kelebihan hasil } \\
\text { laba }\end{array}$ & Persen \\
& $\begin{array}{l}\text { pendapatan (gain) dan rugi, biaya tidak } \\
\text { termasuk bunga, pajak danbagi hasil. }\end{array}$ & \\
& $\begin{array}{l}\text { Perubahan laba merupakan perbedaan } \\
\text { antara pendapatan dalam suatu periode } \\
\text { dan biaya yang dikeluarkan untuk }\end{array}$ & \\
& $\begin{array}{l}\text { mendatangkan perubahan laba. Indikator } \\
\text { perubahan laba yang digunakan dalam }\end{array}$ & \\
& penelitian ini adalah laba sebelum pajak. & \\
\hline $\begin{array}{l}\text { Capital } \\
\text { Rdequacy }\end{array}$ & $\begin{array}{l}\text { Rasio Capital Adequacy Ratio merupakan } \\
\text { perbandingan modal bank dengan Aktiva }\end{array}$ & Rasio \\
& $\begin{array}{l}\text { Tertimbang Menurut Risiko. } \\
\text { Perhitungan rasio CAR sesuai dengan }\end{array}$ & \\
rumus di laporan keuangan bank yang \\
dipublikasikan.
\end{tabular}




\begin{tabular}{|l|l|l|}
\hline Performing & $\begin{array}{l}\text { terhadap total kredit. } \\
\text { Perhitungan rasio NPL sesuai dengan } \\
\text { rumus di laporan keuangan bank yang } \\
\text { dipublikasikan. }\end{array}$ & \\
\hline $\begin{array}{l}\text { Biaya } \\
\text { Operasional } \\
\text { pendapatan } \\
\text { operasional }\end{array}$ & $\begin{array}{l}\text { Rasio Biaya Operasional pendapatan } \\
\text { operasional mengindikasikan efisiensi }\end{array}$ & \\
operasional bank. & $\begin{array}{l}\text { Rerhitungan rasio BOPO sesuai dengan } \\
\text { rumus di laporan keuangan bank yang } \\
\text { dipublikasikan. }\end{array}$ & \\
\hline $\begin{array}{l}\text { Loan } \\
\text { to }\end{array}$ & $\begin{array}{l}\text { Rasio Loan to Deposit Ratio adalah } \\
\text { perbandingan kredit yang diberikan } \\
\text { terhadap dana pihak ketiga. }\end{array}$ & \\
& $\begin{array}{l}\text { Perhitungan rasio LDR sesuai dengan } \\
\text { rumus di laporan keuangan bank yang } \\
\text { dipublikasikan. }\end{array}$ & \\
\hline
\end{tabular}

Sumber : Laporan Keuangan Bank

\section{Populasi, sampel, teknik pengambilan sampel}

Populasi dalam penelitian ini adalah Bank Konvensional yang terdaftar di Bursa Efek Indonesia pada periode 2009-2012. Sampel yang digunakan dalam penelitian ini adalah dipilih secara purposive sampling dengan kriteria sebagai berikut :

a. Bank Konvensional yang terdaftar di Bursa Efek Indonesia.

b. Bank yang sudah go public di Bursa Efek Indonesia dengan tanggal IPO sebelum tahun 2009 dan tidak pernah keluar hingga tahun 2012.

c. Bank Konvensional yang mempublikasikan laporan keuangan tahunan dan rasio-rasio yang dibutuhkan dalam penelitian.

\begin{tabular}{|l|c|}
\hline \multicolumn{1}{|c|}{ Kriteria Bank } & Sampel \\
\hline $\begin{array}{l}\text { Bank yang sudah go public di Bursa Efek Indonesia dengan } \\
\text { tanggal IPO sebelum tahun 2009 dan tidak pernah keluar } \\
\text { hingga tahun 2012 }\end{array}$ & 27 \\
\hline $\begin{array}{l}\text { Bank yang tidak menerbitkan Laporan Keuangan } \\
\text { Tahunan secara lengkap }\end{array}$ & $(3)$ \\
\hline Jumlah sampel bank dalam 1 tahun & 24 \\
\hline Periode pengamatan 4 tahun $=4 \times 24$ & 96 \\
\hline
\end{tabular}

\section{Teknik Analisis Data}

Dalam penelitian ini, semua data variabel dependen dan independen ditranformasi ke bentuk log natural (Ln), karena adanya data rasio yang tidak stabil dan sangat fluktuatif dari tahun ke tahun. Tujuanya adalah untuk menstabilkan data yang bernilai sangat fluktuatif tersebut agar dapat bebas dari penyimpangan hasil analisis. Teknik analisis data adalah sebagai berikut: a. Uji asumsi klasik

Uji asumsi klasik merupakan uji regresi dengan pertimbangan kemungkinan ada penyimpangan, jika terjadi penyimpanganb pada data maka dilakukan perbaikan terhadap data yaitu dilakukan tranformasi agar dapat diolah kelangkah selanjutnya. Pengujian asumsi klasik yang terdiri atas normalitas, heteroskesdatisitas, multikolinearitas, dan autokorelasi. Pengujian dapat diuraikan sebagai berikut: 
1) Uji Normalitas

Uji normalitas bertujuan untuk menguj apakah model regresi, variabel terikat darc) variabel bebas keduanya mempunyai distribusi normal atau tidak. Model regresid) yang baik adalah memiliki distribusi data normal atau mendekati normal. Metode yang) dapat dipakai untuk normalitas antara lain analisis grafik dan analisis statistik. Menurut Ghozali (2011:163) pada prinsipnyd. normalitas dapat dideteksi dengan melihat penyebaran data (titik) pada sumbu diagonal dari grafik atau dengan melihat histogram dari residualnya.

2) Uji Multikolonieritas

Menurut Ghozali (2011) menguji apakah pada model regresi ditemukan adanya korelasi antar variabel independen. Model regresi yang baik seharusnya tidak terjadi korelasi diantara variabel independen. Untuk mendeteksi ada atau tidaknya mulikolonieritas didalam regresi antara lain dapat dilakukan dengan melihat nilai tolerance dan lawannya serta variance factor (VIF). Nilai cut-off yang umum dipakai untuk menunjukkan adanya multikolonieritas adalah nilai tolerance $\leq 0,10$ atau sama dengan nilai $V I F \geq 10$.

\section{3) Uji Heteroskedastisitas}

\section{Menurut \\ Ghozali \\ (2011) \\ uji}

heteroskesdatisitas bertujuan untuk menguji apakah model regresi terjadi ketidaksamaan variance dari residual satu pengamatan ke pengamatan yang lain. Model regresi yang. baik adalah yang homoskesdatisitas atau tidak terjadi heteroskesdatisitas.

\section{4) Uji Autokerelasi}

Menurut Ghozali (2011) uji autokorelasi bertujuan untuk menguji apakah dalam suatu model regresi linear ada korelasi antara kesalahan pengganggu pada periode $t$ dengan kesalahan periode $\mathrm{t}-1$ (sebelumnya). Model regresi yang baik adalah yang bebas autokorelasi. Untuk mendeteksi auto korelasi, dapat dilakukan uji statistik melalui Durbin-Watson (DW test). Pengambilan keputusan ada tidaknya autokorelasi sebagai berikut:

a) Nilai $0<\mathrm{d}<\mathrm{dl}$ maka tidak ada autokorelasi positif. b) Nilai $\mathrm{dl}<\mathrm{d}<\mathrm{du}$ maka tidak ada autokorelasi positif.

Nilai $4-d l<d<4$ maka tidak ada autokorelasi negatif.

Nilai $4-d u<d<4-d l$ maka tidak ada autokorelasi negatif.

Nilai $\mathrm{du}<\mathrm{d}<4$-du maka tidak ada autokorelasi negatif dan positif.

\section{Analisis Regresi}

Penelitian ini bertujuan menguji pengaruh hubungan antara variabel-variabel independen terhadap variabel dependen dengan menggunakan analisis regresi linier berganda. Statistik untuk menguji hipotesis dalam penelitian ini menggunakan metode regresi linier berganda dengan rumus :

$Y=a+b_{1} x_{1}+b_{2} x_{2}+b_{3} x_{3}+b_{4} x_{4}+e$

Keterangan :

Y

: perubahan laba

$a$

: konstanta persamaan

regresi

$b_{1}, b_{2}, b_{3}, b_{4} \quad:$ koefisien regresi

$x_{1} \quad:$ Capital Adequacy Ratio

$(C A R)$

$x_{2} \quad$ : Non Perfoming Loan (NPL)

$x_{3} \quad$ :Biaya $\quad$ Operasional pendapatan operasional (BOPO)

$x_{4} \quad:$ Loan to Deposit Ratio (LDR)

$e$

: standar eror

\section{Uji Hipotesia}

\section{1) Uji Koefisien Determinasi $(R)$}

Menurut Ghozali (2011) uji determinasi $\left(\mathrm{R}^{2}\right.$ ) pada intinya mengukur seberapa jauh kemampuan model dalam menerangkan variasi variabel dependen. Nilai $R^{2}$ berkisar 0 $<\mathrm{R}^{2}<1$, semakin besar $\mathrm{R}^{2}$ maka variabel bebas semakin dekat hubungannya dengan variabel tidak bebas, dengan kata lain model tersebut dianggap baik.

\section{2) Uji Pengaruh Simultan (Uji F)}

Menurut Ghozali (2011) uji statistik F pada dasarnya menunjukkan apakah semua variabel independen yang dimasukkan kedalam model, mempunyai pengaruh secara bersama-sama terhadap variabel dependen 


\section{JURNAL AKUNTANSI VOL.3 NO. 1 JUNI 2015}

secara signifikan. Uji ini dapat dilakukan dengan syarat:

a) Jika $\mathrm{F}$ hitung $<\mathrm{F}$ tabel, maka $\mathrm{Ho}$ diterima yaitu variabel-variabel independen secara simultan tidak berpengaruh terhadap variabel dependen.

\section{HASIL DAN PEMBAHASAN}

b) Jika F hitung $>$ F tabel, maka Ho ditolak yaitu. variabel-variabel independen secara simultan berpengaruh terhadap variabel dependen.

\section{3) Uji Statistik t}

Menurut Ghozali (2011) uji t (t-test) dilakukan untuk menguji apakah secara terpisah variabel independen mampu menjelaskan variabel dependen secara baik.

Dasar pengambilan keputusan:

Jika thitung > ttabel , maka H0 tidak didukung, Ha didukung

Jika thitung < ttabel, maka H0 didukung, Ha tidak didukung.

Berdasarkan probabilitas yaitu dengan membandingkan nilai dengan $\alpha(0,05)$ yaitu:
Jika sig $<0,05$ maka H0 tidak didukung, $\mathrm{Ha}$ didukung.

Jika sig > 0,05 maka H0 didukung, Ha tidak didukung.

\section{Deskriptif Statistik Variabel Penelitian}

Untuk memberikan gambaran dan informasi mengenai data variabel dalam penelitian ini maka digunakanlah tabel statistik deskriptif. Tabel statistik deskriptif ini meliputi nilai rata-rata (mean), jumlah data $(\mathrm{N})$ dan standar deviasi dari empat variabel independen yaitu perubahan laba, Capital Adequacy Ratio (CAR), dan Non Performing Loan (NPL), Biaya Operasional Pendapatan Operasional (BOPO), dan Loan to Deposit Ratio (LDR) sebagai variabel yang mempengaruhi perubahan laba. Hasil analisis deskriptif statistik data asli dan data yang sudah ditransformasi dalam bentuk log natural ( $L n$ ) akan ditunjukkan sebagai berikut :

Descriptive Statistics ( Data Asli)

\begin{tabular}{|l|r|r|r|r|r|}
\hline & \multicolumn{1}{|c|}{$\mathrm{N}$} & \multicolumn{1}{c|}{ Minimum } & \multicolumn{1}{c|}{ Maximum } & \multicolumn{1}{c|}{ Mean } & Std. Deviation \\
\hline LnPerubahan & 96 & -97.31 & 378.61 & 53.9436 & 63.8598 \\
Laba & & & & & \\
LnCAR & 96 & 8.20 & 46.79 & 16.5946 & 5.79480 \\
LnNPL & 96 & .07 & 58.00 & 2.9401 & 6.24504 \\
LnBOPO & 96 & 25.20 & 157.50 & 82.9156 & 18.33800 \\
LnLDR & 96 & 40.20 & 100.60 & 77.2739 & 13.68533 \\
Valid N & 96 & & & & \\
(listwise) & & & & & \\
\hline
\end{tabular}

Descriptive Statistics (Data Ln)

\begin{tabular}{|l|r|r|r|r|r|}
\hline & \multicolumn{1}{|c|}{$\mathrm{N}$} & Minimum & Maximum & Mean & Std. Deviation \\
\hline LnPerubahan & 96 & 2.49 & 5.94 & 3.9533 & .68347 \\
Laba & & & & & \\
LnCAR & 96 & 2.10 & 3.85 & 2.7639 & .28670 \\
LnNPL & 96 & -2.66 & 4.06 & .5151 & .95220 \\
LnBOPO & 96 & 3.23 & 5.06 & 4.3885 & .26345 \\
LnLDR & 96 & 3.69 & 4.61 & 4.3295 & .19774 \\
Valid N & 96 & & & & \\
(listwise) & & & & & \\
\hline
\end{tabular}


Berdasarkan tabel Descriptive Statistics dapat dilihat bahwa dengan valid $\mathrm{N}=87$ waktu amatan. Berkurangnya sampel 96 menjadi 87 tidak mempengaruhi hasil pengujian. Penyebab berkurangnya sampel karena ada data yang bernilai negative pada data asli sehingga ketika ditransformasi ke dalam bentuk log natural (Ln) data tersebut tereliminasi. Data yang tereliminasi tersebut ada pada variabel perubahan laba berkurang menjadi 87 .

\section{Uji Asumsi Klasik}

a) Uji Normalitas

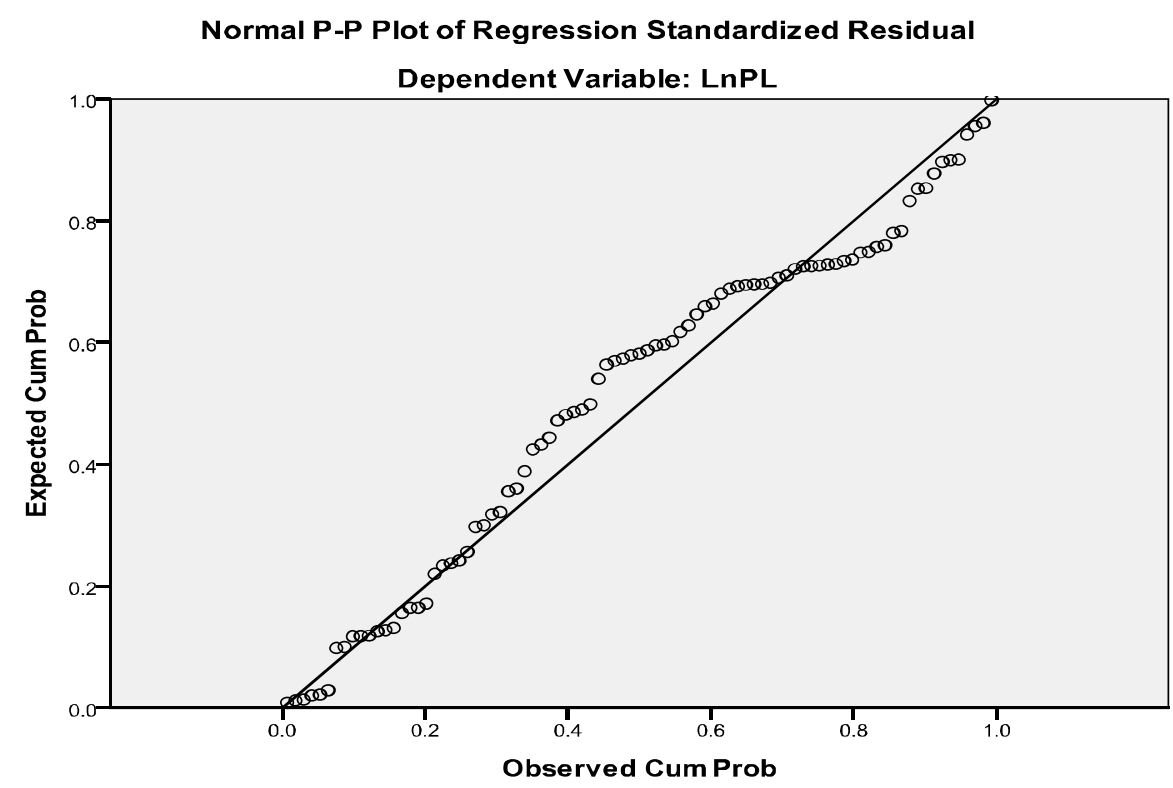

Berdasarkan gambar Normal P-P Plot of Regression standardized Residual menunjukkan pola data terdistribusi disekitar garis diagonal serta menyebarnya mengikuti arah garis diagonal. normal, terlihat titik-titik menyebar

\section{One-Sample Kolmogorov-Smirnov Test}

\begin{tabular}{|ll|r|}
\hline & & $\begin{array}{r}\text { Unstandardiz } \\
\text { ed Residual }\end{array}$ \\
\hline $\mathrm{N}$ & Mean & 87 \\
Normal & Std. Deviation & .0000000 \\
Parameters ${ }^{\mathrm{a}, \mathrm{b}}$ & .62596423 \\
Most Extreme & Absolute & .117 \\
Differences & Positive & .086 \\
& Negative & -.117 \\
Kolmogorov-Smirnov Z & 1.092 \\
Asymp. Sig. (2-tailed) & .184 \\
\hline
\end{tabular}

a. Test distribution is Normal.

b. Calculated from data. 


\section{JURNAL AKUNTANSI VOL.3 NO. 1 JUNI 2015}

Berdasarkan tabel One Sample Kolmogorov-Smirnov Test dapat dilihat dari nilai signifikansi yang ditunjukkan pada Asymp. Sig. (2-tailed) sebesar 0,184 . Nilai signifikansi lebih dari 0,05 maka data tersebut terdistribusi normal.

\section{b) Uji Multikolonieritas}

\section{Coefficients $^{\mathrm{a}}$}

\begin{tabular}{|l|r|r|}
\hline \multirow{2}{*}{ Model } & \multicolumn{2}{|c|}{ Collinearity Statistics } \\
\cline { 2 - 3 } (Constant) & Tolerance & \multicolumn{2}{|c|}{ VIF } \\
LnCAR & .904 & 1.107 \\
LnNPL & .795 & 1.258 \\
LnBOPO & .805 & 1.243 \\
LnLDR & .907 & 1.103 \\
\hline
\end{tabular}

a. Dependent Variable: Perubahan laba

Berdasarkan tabel 4.4, dapat dilihat nilai tolerance dan VIF dari variabel LnCAR adalah sebesar 0,904 dan 1,107. Untuk variabel LnNPL adalah sebesar 0,795 dan 1,258. Untuk variabel LnBOPO adalah sebesar 0,805 dan 1,243. Untuk variabel LnLDR adalah sebesar
0,907 dan 1,103. Oleh karena itu dapat disimpulkan bahwa dalam model ini tidak terdapat masalah multikolinearitas antara variabel bebas karena nilai tolerance berada di bawah 1 dan nilai VIF jauh di bawah angka 10 .

\section{c) Uji Heteroskesdatisitas}

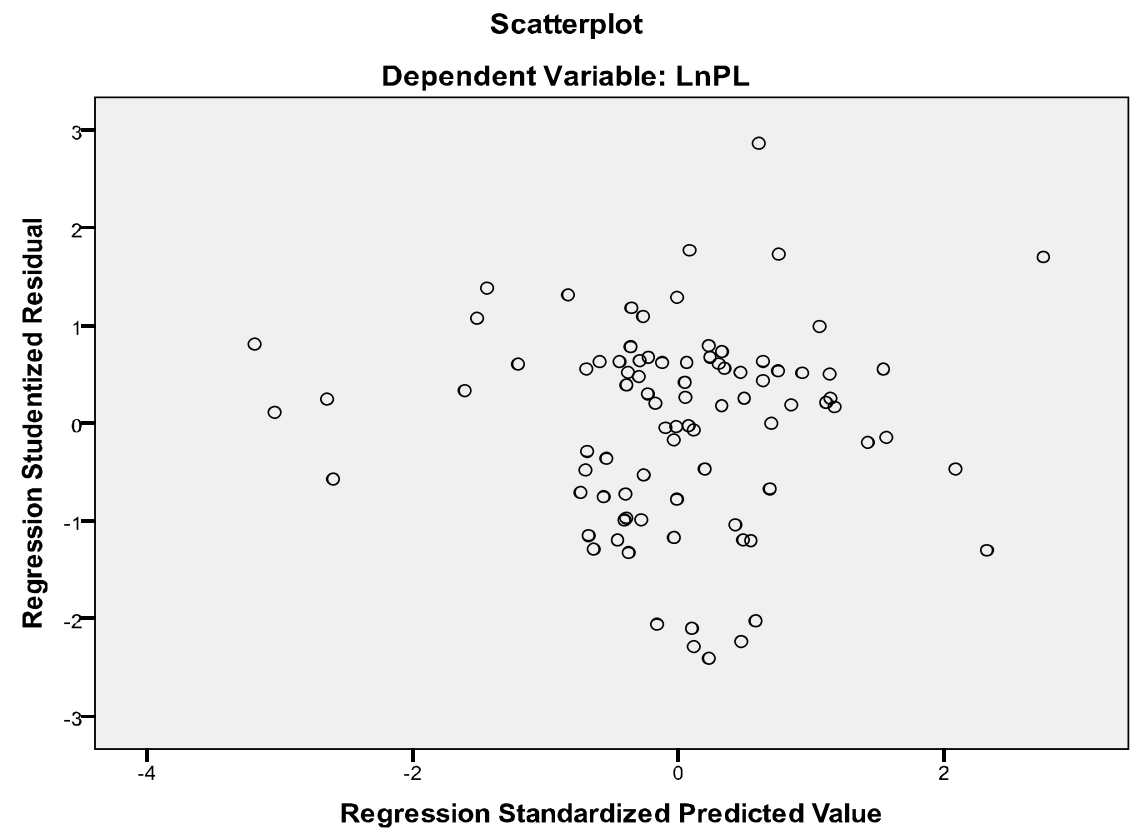

Berdasarkan gambar 4.3 dapat diliahat secara acak serta tersebar di atas maupun di bawah angka 0 pada sumbu Y. Hal ini berarti tidak terjadi 
heteroskidastisitas pada model regresi, sehingga model regresi layak dipakai untuk prediksi pengaruh perubahan laba berdasarkan masukan Capital Adequacy
Ratio (CAR), Non Perfoming Loan (NPL), Biaya Operasioanal Pendapatan Operasional, dan Loan To Deposit Ratio (LDR).

\section{d) Uji Autokorelasi}

\begin{tabular}{|c|c|c|c|c|c|}
\hline \multicolumn{6}{|c|}{ Model Summary } \\
\hline $\begin{array}{l}\text { Mode } \\
1\end{array}$ & $\mathrm{R}$ & R Square & $\begin{array}{l}\text { Adjusted R } \\
\text { Square }\end{array}$ & $\begin{array}{l}\text { Std. Error of } \\
\text { the Estimate }\end{array}$ & $\begin{array}{l}\text { Durbin- } \\
\text { Watson }\end{array}$ \\
\hline 1 & $\begin{array}{r}.401 \\
\mathrm{a}\end{array}$ & .161 & .120 & .64105 & 1.862 \\
\hline
\end{tabular}

a. Predictors: (Constant), LnLDR, LnBOPO, LnCAR, LnNPL

b. Dependent Variable: LnPL

Berdasarkan hasil perhitungan tabel dapat diketahui bahwa nilai DurbinWatson 1,862 lalu hasil ini dibandingkan dengan nilai dl dan du pada tabel DurbinWatson. penelitian ini menggunkan jumlah sempe 96, dengan variabel independen 4 maka diperoleh nilai du sebesar 1,7553 dan dl sebesar 1,5821. Syarat penelitian untuk dapat dinyatakan bebas autokorelasi adalah $\mathrm{du}<\mathrm{d}<(4-\mathrm{du})$, dari hasil nilai hitung tersebut maka tidak terjadi autokorelasi pada model regresi yang digunakan dalam penelitian ini.

\section{Analisis Regresi}

\begin{tabular}{|c|c|c|c|c|c|c|}
\hline & & \multicolumn{5}{|c|}{ Coefficients $^{\mathrm{a}}$} \\
\hline & & \multicolumn{2}{|c|}{$\begin{array}{c}\text { Unstandardized } \\
\text { Coefficients }\end{array}$} & \multirow{2}{*}{$\begin{array}{c}\text { Standardize } \\
\mathrm{d} \\
\text { Coefficients } \\
\\
\text { Beta }\end{array}$} & \multirow[b]{2}{*}{$\mathrm{T}$} & \multirow[b]{2}{*}{ Sig. } \\
\hline \multicolumn{2}{|c|}{ Model } & $\mathrm{B}$ & $\begin{array}{l}\text { Std. } \\
\text { Error }\end{array}$ & & & \\
\hline \multirow[t]{5}{*}{1} & $\begin{array}{l}\text { (Constan } \\
\text { t) }\end{array}$ & 2.546 & 2.286 & & 1.114 & .269 \\
\hline & LnCAR & 1.051 & .249 & .422 & 2.203 & .004 \\
\hline & LnNPL & -.122 & .079 & -.176 & -.548 & .125 \\
\hline & LnBOPO & -.669 & .281 & -.268 & -.377 & .198 \\
\hline & LnLDR & .733 & .360 & .598 & 2.925 & .001 \\
\hline
\end{tabular}

a. Dependent Variable: Perubahan Laba

Berdasarkan tabel Coefficient dengan memperhatikan angka yang berada pada kolom Unstandardized
Coefficient Beta, maka dapat disusun persamaan regresi berganda sebagai berikut:

Perubahan laba $=2,546+1,051 X_{1}-0,122 X_{2}-0,669 X_{3}+0,733 X_{4}$

Dari persamaan regresi, maka dapat disimpulkan sebagai berikut : a. Nilai konstanta persamaan diatas adalah sebesar 2,546. Angka tersebut menunjukkan perubahan laba yang 
diperoleh bank sebesar 2,546 bila CAR $\left(X_{1}\right)$, NPL $\left(X_{2}\right)$, BOPO $\left(X_{3}\right)$, dan LDR $\left(X_{4}\right)$ dianggap konstan.

b. Variabel Capital Adequacy Ratio (CAR) memiliki nilai koefisien yang positif yaitu sebesar 1,051. Nilai koefisien positif menunjukkan bahwa CAR terhadap perubahan laba berpengaruh positif. Hal ini menggambarkan bahwa jika terjadi kenaikan CAR sebesar $1 \%$, maka menyebabkan kenaikan perubahan laba sebesar 0,828 dengan asumsi variabel independen yang lain dianggap konstan.

c. Variabel Non Performing Loan (NPL) memiliki nilai koefisien regresi yang negatif yaitu sebesar - 0,122 dengan nilai signifikansi diatas 0,05 yaitu sebesar 0,125, maka NPL tidak berpengaruh terhadap perubahan laba. d. Variabel Biaya Operasional Pendapatan Operasional (BOPO) memiliki nilai koefisien regresi yang negatif yaitu sebesar - 0,669 dengan nilai signifikansi diatas 0,05 yaitu sebesar 0,198, maka BOPO tidak berpengaruh terhadap perubahan laba.

e. Variabel Loan to Deposit Ratio (LDR) memiliki nilai koefisien yang positif yaitu sebesar 0,733 . Nilai koefisien yang positif menunjukkan bahwa LDR terhadap perubahan laba berpengaruh positif. Hal ini menggambarkan bahwa jika terjadi kenaikan LDR sebesar $1 \%$, maka menyebabkan kenaikan terhadap perubahan laba sebesar 0,733 dengan asumsi bahwa variabel independen yang lain dianggap konstan.

\section{Uji Hipotesis}

a) Koefisien Determinasi $\left(R^{2}\right)$

Model Summary ${ }^{b}$

\begin{tabular}{|l|r|r|r|r|r|}
\hline Model & R & R Square & $\begin{array}{c}\text { Adjusted R } \\
\text { Square }\end{array}$ & $\begin{array}{c}\text { Std. Error of } \\
\text { the Estimate }\end{array}$ & Durbin-Watson \\
\hline 1 & $.401^{\mathrm{a}}$ & .161 & .120 & .64105 & 1.862 \\
\hline
\end{tabular}

a. Predictors: (Constant), LnLDR, LnBOPO, LnCAR, LnNPL

b. Dependent Variable: LnPL

Berdasarkan tabel Model Summary dapat diketahui bahwa nilai koefisien determinansi ( adjusted $R^{2}$ ) sebesar 0,120 . hal ini menunjukkan bahwa sebesar 12,0\% perubahan laba yang bisa dijelaskan oleh variasi dari keempat variabel independen yang digunakan, yaitu Capital Adequacy Ratio (CAR), Non Performing Loan (NPL), Biaya Operasional Pendapatan Operasional (BOPO), dan Loan To Deposit Ratio (LDR). Sedangkan sisanya sebesar $88 \%$ dijelaskan oleh variabel diluar model penelitian . 
nasabah terhadap terhadap bank yang pada akhirnya dapat meningkatkan laba perbankan.

2) Uji hipotesis pengeruh Non Performing Loan (NPL) terhadap Perubahan Laba

Berdasarkan pengujian parsial (Uji-t) diperoleh hasil bahwa Non Performing Loan tidak berpengaruh terhadap perubahan laba. Hal ini ditunjukkan dengan nilai $t$ hitung lebih kecil dari t tabel $(-0,548<1,986377)$ dengan nilai signifikansi 0,125 . Pengaruh negatif sesuai dengan teori yang mendasari menyatakan bahwa Semakin kecil NPL berarti semakin kecil pula resiko yang ditanggung pihak bank. Demikian sebaliknya semakin besar NPL maka semakin besar resiko kegagalan kredit yang disalurkan, yang berpotensi menurunkan pendapatan bunga serta menurunkan laba. Tingkat signifikan lebih dari 0,05 maka dalam hal ini pengaruh NPL terhadap perubahan laba tidak dapat diartikan. maka dinyatakan hipotesis kedua yang menyatakan Non Performing Loan negatif, tidak terdukung.

Dalam penelitan Dewanti (2009) menyebutkan bahwa penyebab NPL tidak berpengaruh signifikan, karena kondisi yang belum normal menyebabkan jumlah kredit bermasalah yang ada di perbankan semakin besar sehingga bank dalam kondisi bermasalah sehingga laba yang diperoleh kecil.

\section{3) Uji hipotesis pengaruh Biaya} Operasional Pendapatan Operasional (BOPO) terhadap perubahan laba

Berdasarkan pengujian parsial (Uji-t) diperoleh hasil bahwa Biaya Operasional Pendapatan Operasional tidak berpengaruh terhadap perubahan laba. Hal ini ditunjukkan dengan nilai t hitung lebih kecil dari t tabel ($0,377<1,986377)$ dengan nilai signifikan 0,198 , maka hipotesis ketiga menyatakan BOPO berpengaruh negatif, tidak terdukung. Nilai negatif yang ditunjukkan BOPO sesuai dengan teori yang mendasarinya bahwa semakin kecil BOPO menunjukkan semakin efisien bank dalam menjalankan usahanya.
Tingkat signifikan BOPO lebih dari 0,05, karena penurunan yang diperoleh oleh bank disebabkan adanya penurunan pendapatan non operasional dan peningkatan biaya non operasional. Dalam penelitian Setyarini (2009) menyebutkan bahwa semakin meningkatnya BOPO menunjukkan bank tidak efisien dalam menjalankan aktifitas operasionalnya. Besarnya biaya operasional yang dikeluarkan tidak diikuti dengan peningkatan pendapatan operasional yang diperoleh.

\section{4) Uji hipotesis terhadap Loan to}

\section{Deposit Ratio (LDR) terhadap perubahan}

laba

Berdasarkan pengujian parsial (Uji-t) diperoleh hasil bahwa Loan to Deposit Ratio berpengaruh positif dan signifikan terhadap perubahan laba. Hal ini ditunjukkan dengan nilai $\mathrm{t}$ hitung lebih besar $\mathrm{t}$ tabel $(2,925>1,986377)$ dengan nilai signifikan 0,001, maka hipotesisis keempat yang menyatakan Loan to Deposit Ratio berpengaruh positif, terdukung. Nilai positif dan signifikan yang ditunjukkan LDR sesuai dengan teori yang mendasarinya bahwa semakin tinggi LDR maka semakin besar dana yang disalurkan dan akan meningkatkan pendapatan bank, berarti semakin besar LDR suatu bank semakin besar pula perubahan laba bank.

\section{Kesimpulan Dan Saran}

1. Kesimpulan

a) Berdasarkan hasil pengujian secara simultan, variabel Capital Adequacy Ratio (CAR), Non Performing Loan (NPL), Biaya Operasional Pendapatan Operasional (BOPO), dan Loan to Deposit Ratio (LDR) yang ada pengaruh bersama-sama terhadap variabel perubahan laba. Hal ini ditunjukkan dengan hasil pengujian model nilai $\mathrm{F}$ hitung 3,939 > F tabel 2,467494, dengan tingkat signifikansi 0,006 (jauh lebih kecil dari 0,05) maka variabel Capital Adequacy Ratio (CAR), Non Performing Loan (NPL), Biaya Operasional Pendapatan Operasional (BOPO), dan Loan to Deposit Ratio (LDR) berpengaruh secara simultan terhadap perubahan laba. 
b) Berdasarkan pengujian parsial (Uji t), variabel Capital Adequacy Ratio (CAR) memiliki pengaruh positif dan signifikan terhadap perubahan laba. Non Performing Loan (NPL) tidak pengaruh terhadap perubahan laba. Biaya Operasional Pendapatan Operasional (BOPO) tidak berpengaruh terhadap perubahan laba. Loan to Deposit Ratio (LDR) memiliki pengaruh positif dan signifikan terhadap perubahan laba.

c) Hasil Adjusted $R$ Square dari model regresi dalam penelitian ini menunjukkan bahwa variabel-variabel independen yang mampu menjelaskan perubahan laba sebesar $12,0 \%$, sedangkan sisanya $88 \%$ dijelaskan oleh faktor lain di luar model yang tidak dimasukkan di model ini.

\section{Implikasi}

a) Implikasi Teoristis

1) Setyarini (2009), hasil penelitian tersebut menyatakan bahwa CAR berpengaruh positif dan signifikan terhadap perubahan laba.

2) Artwenda (2009), hasil penelitian tersebut menyatakan bahwa NPL berpengaruh negatif dan tidak signifikan terhadap perubahan laba.

3) Pahlevie (2009), hasil penelitian tersebut menyatakan bahwa BOPO berpengaruh negatif dan tidak signifikan terhadap perubahan laba.

4) Ariyanti (2010), hasil penelitian tersebut menyatakan bahwa LDR berpengaruh positif terhadap perubahan laba.

\section{b) Implikasi kebijakan manajerial}

Berdasarkan hasil analisis regresi, variabel yang memiliki pengaruh signifikan terhadap perubahan laba adalah variabel Capital Adequacy Ratio (CAR) dan Loan to Deposit Ratio(LDR). Maka perusahaan diharapkan dapat lebih memperhatikan dua variabel tersebut untuk meningkatkan perubahan laba. Hal ini menunjukan bahwa LDR mempunyai pengaruh yang cukup signifikan terhadap besar kecilnya perolehan laba bank. Jika bank dalam penyaluran kredit dari pihak ketiga tinggi, maka LDR juga tinggi karena dana dari pihak ketiga dapat dimaksimalkan dalam bentuk kredit. Jika kredit meningkat, maka pendapatan bunga dari kredit tersebut juga akan meningkat yang berdampak pada tingginya perolehan laba bank. Sehingga laba yang diterima bank akan tinggi maka berpengaruh terhadap perubahan laba, bank yang mempunyai CAR tinggi berarti bank tersebut memiliki modal yang cukup untuk melaksanakan kegiatan usahanya, dan cukup untuk menanggung risiko apabila bank dilikuidasi.

\section{Saran}

a. Dalam penelitian yang dilakukan, empat variabel independen CAR, NPL, BOPO, dan LDR hanya mampu menjelaskan perubahan laba sebesar $12,0 \%$ yang ditunjukkan pada nilai adjusted $R$ sedangkan sisanya sebesar $88 \%$ dijelaskan oleh faktor lain di luar model yang tidak dimasukkan di model ini. Sehingga disarankan untuk penelitian yang akan datang diharapkan menambah variabel lain yang tidak dimaksukkan dalam penelitian ini. Karena dari penelitian menunjukkan hanya dua variabel yang berpengaruh positif dan signifikan terhadap perubahan laba.

b. Bagi peneliti selanjutnya disarankan untuk memperbanyak sampel yang digunakan agar hasilnya lebih baik terhadap populasi yang dipilih, serta menambah periode penelitian.

\section{Keterbatasan Penelitian}

Sebagaimana diuraikan dimuka bahwa hasil penelitian ini terbatas pada pengamatan yang relatif pendek yaitu selama 4 tahun dengan sampel terbatas (96 sampel). Disamping itu rasio-rasio bank yang digunakan sebagai dasar memprediksi laba hanya terbatas, yaitu CAR, NPL, BOPO, dan LDR. 


\section{DAFTAR PUSTAKA}

Ali. Masyhud. (2004). Asset Liability Management: Manyiasati Risiko Pasar dan

Risiko Operasional. PT. Gramedia Jakarta.

Artwienda, Nur. 2009. Analisis Pengaruh Capital Adequacy Ratio, Non Performing Loan, BOPO, Net Interest Margin, Dan Loan To Deposit Ratio Terhadap Perubahan Laba Periode 2004 - 2007. Tesis : Universitas Diponegoro Semarang. Diplubikasikan.

Ariyanti, Lilis Erna.2010. Analisis Pengaruh CAR, NIM, LDR, NPL, BOPO, ROA, dan kualitas Aktiva Produktif Terhadap Perubahan Laba pada Bank Umum di Indonesia. Tesis : Universitas Diponegoro Semarang. Dipublikasikan.

Aviliani.2007. Persoalan- Persoalan Perbankan Diindonesia. Gorga Media. Jakarta.

Dendawijaya. Lukman. 2001. Manajemen Perbankan. Jakarta. Ghalia Indonesia.

------------., 2005. Manajemen

Perbankan. Jakarta. Ghalia Indonesia.

Desfian, Basran. 2003. Analisis Faktor-

Faktor Yang Berpengaruh Terhadap

Kinerja Bank Umum di Indonesia

Tahun 2001-2003. Tesis : Universitas

Diponegoro

Semarang.

Dipublikasikan.

Dewanti, Hestina wahyu. 2009. Analisis Pengaruh Perubahan NPM, LDR, NPL dan BOPO Terhadap Perubahan Laba. Tesis: Universitas Diponegoro Semarang. Dipublikasikan.

Ediningsih, Sri Isworo. 2004. Rasio

Keuangan dan Prediksi Pertumbuhan

Laba. Studi Empiris pada

Perusahaan Manufaktur di BEJ. Jurnal akuntansi . Vol 7. No 1.

Februari. hal 29-42.

Ghozali, Imam. 2011. Aplikasi Analisis

Multivariante dengan program IBM

SPSS 19. Semarang. Badan Penerbit

Universitas Diponegoro
Kasmir. 2001. Bank dan Lembaga Keuangan Lainnya (Edisi Keenam). Jakarta: Raja Grafindo Persada.

Khotimah. Sarah Zahrotul. 2011. Analisis Pengaruh CAR, NPL, BOPO, NIM, dan LDR terhadap Perubahan Laba pada Bank Devisa di Indonesia tahun 2005-2008. Skripsi: Universitas Diponegoro Semarang. Dipublikasikan.

Komang, Darmawan. 2004. Analisis Rasio-Rasio Bank. Info Bank, Juli, 18-21

Kuncoro M., Suhardjono, 2002, Manajemen Perbankan : Teori dan Aplikasi, Cetakan Pertama, BPFE, Yogyakarta.

Lestari, Venny Dwi. Analisis Tingkat Kesehatan Bank-bank Pemerintah Dengan Menggunakan Metode CAMEL dan Analisis Diskriminan Periode 2006 2008. Jurnal akuntansi dan bisnis : Universitas Gunadarma

Mabruroh, (2004. Manfaat Pengaruh Rasio Keuangan dalam Analisis Kinerja Keuangan Perbankan. Jurnal akuntansi. Vol.8, No.1, Juni 2004

Muljono, Teguh Pudjo. 1999. Analisis Laporan Keuangan Untuk Perbankan. Jakarta: Djambatan.

Mudrajat Kuncoro, Suhardjono (2002). Manajemen Perbankan, Teori dan Aplikasi. BPFE Yogyakarta.

Munawir, S., Analisa Laporan Keuangan, Liberty, Yogyakarta, 2000.

Meriawaty, Setyani, 2005, Analisis Rasio Keuangan terhadap Perubahan Kinerja pada Perusahaan di Industri Food and Baverage yang Terdaftar di BEJ, Makalah yang disampaikan pada Simposium Nasional Akuntansi VIII, Solo, 15-16 September.

Nazhiifah, Nur Wirdatin. 2011. Analisis Pengaruh Tingkat Kinerja Bank dengan Menggunakan Rasio CAMEL Terhadap Ekpansi Kredit Bank Umum Milik Negara dan 
Bank Umum Swasta Nasional Periode 2004-2009. Skripsi: Universitas Sebelas Maret Surakarta.

Pahlevie, Nu'man Hamzah. 2009. Analisis Pengaruh CAR, NIM, LDR, NPL, BOPO, dan EAQ terhadap Perubahan Laba. Tesis: Universitas Diponegoro Semarang.

Prastowo, Dwi dan Rifka Juliaty. 2002. Analisis Laporan Keuangan. Edisi Revisi. AMP YKPN. Yogyakarta.

Putri, Thaussie Nurvigia Dwi Prabowo. 2010. Pengaruh Rasio-Rasio Keuangan Terhadap Perubahan Laba pada Perusahaan Otomotif yang Terdaftar Di Bursa Efek Indonesia. Skripsi : Universitas Pembangunan Nasional "VETERAN" Jakarta.

Dipublikasikan.

Rusdiana, Nana. 2012. Analisis Pengaruh CAR, LDR, NIM, NPL, BOPO dan DPK terhadap Kinerja Keuangan Perbankan. Skripsi: Universitas Diponegoro Semarang. Dipublikasikan.

Sarifudin, Muhammad. 2005. Analisis Pengaruh Rasio-Rasio Keuangan Terhadap Perubahan Laba. Tesis: Universitas Diponegoro Semarang. Dipublikasikan.

Sapariyah, Rina Ani. Pengaruh Rasio Capital, Assets, Earning dan Liquidity terhadap Pertumbuhan Laba Pada Perusahaan Perbankan. Jurnal akuntansi : STIE "AUB" Surakarta.

Setyarini, Adhista. Analisis Pengaruh CAR, NIM, BOPO, LDR, dan GWM terhadap Perubahan Laba Pada Bank Pembangunan Daerah di Indonesia. Tesis: Universitas Diponegoro Semarang. Dipublikasikan.

Surat Edaran Bank Indonesia No. 10 tahun 1998 Perihal Perubahan Atas Undang-Undang No. 7 Tahun 1992 Tentang Perbankan.

Surat Edaran No. 13/6/DPNP 2011 tanggal 18 Februari 2011 Perihal Pedoman
Perhitungan Aset Tertimbang Menurut Risiko untuk Risiko Kredit Dengan Menggunakan Pendekatan Standar.

Suwardjono. 2012. Teori Akuntansi Perekayasaan Pelaporan Keuangan. Yogyakarta. BPFE.

Tarmidzi Achmad, dan Wilyanto Kartiko Kusumo. 2003. Analisis Rasio-rasio Keuangan Sebagai Indikator Dalam Memprediksi Kebangkrutan Perbankan di Indonesia. Media Ekonomi dan Bisnis, Vol. XV 1 Juni - 2003 FE-UNDIP, Semarang.

Tadi, Mochamad. 2005. Analisis Capital Adequacy Ratio, Loan to Deposit Ratio, dan Return on Assets serta Pengaruhnya terhadap Harga Saham Perusahaan Perbankan yang Terdaftar di Bursa Efek Jakarta. Skripsi: Universitas Negeri Semarang. Dipublikasikan

Taswan. 2005. Akuntansi Perbankan Transaksi dalam Valuta Rupiah. Yogyakarta.

2010. Manajemen Perbankan. Yogyakarta. UUP STIM YKPN Yogyakarta.

Triono, Sunarwan. 2007. Analisis FaktorFaktor yang Mempengaruhi Perubahan Laba Satu Tahun dan Dua Tahun Mendatang. Tesis: universitas diponegoro semarang. Dipublikasikan.

Zainuddin dan Jogiyanto Hartono. 1999. Manfaat Rasio Keuangan dalam Memprediksi Pertumbuhan Perubahan Laba: Suatu Studi Empiris pada Perusahaan Perbankan yang Terdaftar di BEJ. Jurnal Riset Akuntansi Indonesia. Vol.2. No.1. Januari, 1999, hal.66-90.

Zulfadin, Rahadian dan Anita Febryani. 2003. Analisis Kinerja Bank Devisa dan Non Devisa di Indonesia. Kajian Ekonomi dan Keuangan. Vol. 7, No. 4.

http://shyawarma.blogspot.com/2012/05/pe rubahan-laba.html diakses 17 Maret 2014 pukul 11:01 PM. 